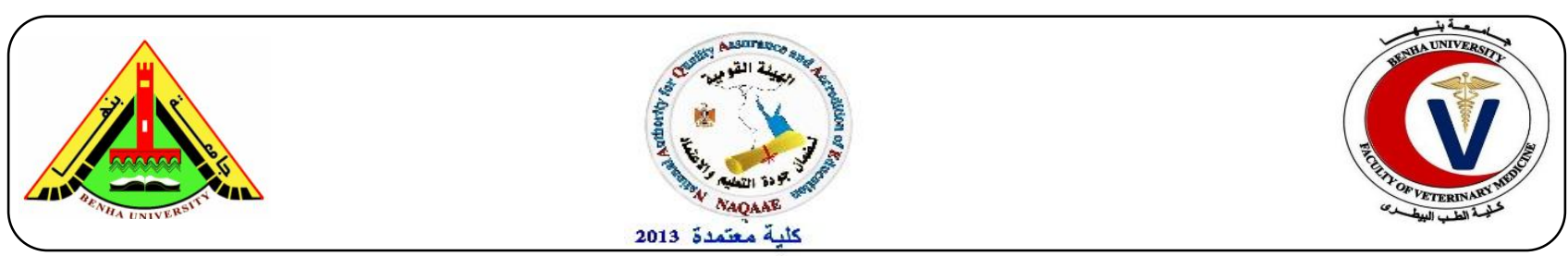

\title{
Biochemical Effect of Zolderonic Acid on Experimentally Induced Degeneration of Pancreas
}

\author{
Abdel-Maksoud H.A.; Omnia M. A. and El-Bialy M.
}

Department of Biochemistry, Faculty of Veterinary Medicine, Benha University

\section{A B S T R A C T}

A total number of 160 Wister female rats, 12 -wk. old were taken, weighed and divided into five experimental groups to investigate the effect of streptozotocin (STZ) injection (30 and $60 \mathrm{mg} / \mathrm{kg}$ B.W) with and without zoledronic acid $(0.15 \mathrm{mg} / \mathrm{kg}$ B.W) on some blood serum constituents such as glucose, insulin, calcium, phosphorus and vitamin D. The current results showed that, injection with STZ was associated with a statistically significant elevated in serum glucose, while there was a decrease in serum insulin, calcium and phosphorus. However, zoledronic treatment resulted in a decrease in serum glucose, mean - while it elevate serum insulin, calcium and phosphorus. toward normal Level These results indicated that ZOL acid has beneficial effect on pancreatic biochemical parameters in case of degenerated pancreas.

Keywords: STZ, Zoledronic acid, pancreas.

(http://www.bvmj.bu.edu.eg) (BVMJ-35(1): 171-177,2018)

\section{INTRODUCTION}

Disorders of the pancreas, both endocrine (e.g. diabetes mellitus) and exocrine (e.g. chronic pancreatitis or cystic fibrosis), can be triggered by different genetic factors. There exist specific mutations which can directly lead to the development of certain pancreatic diseases. A little more than a half century ago, mankind knew a significant amount about these disorders clinically, however at that time not much was known about their genetic background (Németh et al., 2014). The selective destruction of the pancreatic $\beta$-cells by chemical agents has been used to establish diabetic animal models. Streptozotocin (STZ), is a glucosamine-nitrosourea compound derived from Streptomyces achromogenes STZ damages pancreatic $\beta$ cells, resulting in hypoinsulinemia and hyperglycemia (Lenzen, 2008).

Bisphosphonates are pyrophosphate analogues which were used for over a century in industry (mainly in the textile and oil industries) as anti-scaling and anticorrosive agents because of their property of inhibition of calcium carbonate precipitation. After the discovery of biological effects of bisphosphonates more than 30 years ago, they have now become indispensable in medicine for the treatment of skeletal complications of malignancy, Paget's disease, osteoporosis, multiple myeloma, hypercalcemia and fibrous dysplasia (Sirmahan et al., 2012). Zoledronic acid is a nitrogen-containing third-generation bisphosphonate. The nitrogen-containing 
bisphosphonates act by inhibiting farnesyl pyrophosphate synthase (FPPS), a key regulatory enzyme in the mevalonic acid pathway, thereby preventing protein prenylation of guanosine triphosphatebinding proteins that are critical in the regulation of core osteoclast cellular activities, thus ultimately leading to osteoclast apoptosis (Drake et al., 2008). Therefore, the objective of this study aimed to investigate the potential effect of zoledronic acid on experimentally induced degeneration of pancreas by $\beta$ - cell destruction using STZ.

\section{MATERIALS AND METHODS}

This study was carried out at biochemistry Dept., faculty of veterinary medicine, Benha University. One hundred and Sixty Wister female rats, 12 -wks-old were taken, weighed and randomly distributed into five experimental groups. Rats were housed in separate metal cages, Where the five experimental groups were divided as, the first as a control group (non-treated), the second group injected with $30 \mathrm{mg} \mathrm{STZ/} \mathrm{kg} \mathrm{BW}$, the third group injected with $60 \mathrm{mg} \mathrm{STZ} / \mathrm{kg}$, the fourth group injected with $30 \mathrm{mg} \mathrm{STZ}$ plus $0.15 \mathrm{mg} \mathrm{ZOL} / \mathrm{kg}$ and the fifth group injected with $60 \mathrm{mg} \mathrm{STZ}$ plus $0.15 \mathrm{mg}$ ZOL/ kg BW to studying their effects on some sera parameters such as glucose, insulin, calcium, phosphorus and vitamin D at 14 and 28 day after treatment.

Experimental partial degenerated pancreas was induced by a single intraperitoneal injection of streptozotocin with $30 \mathrm{mg} / \mathrm{kg}$ and completely degenerated pancreas was induced by a single intraperitoneal injection of streptozotocin by $60 \mathrm{mg} / \mathrm{kg}$. Streptozotocin (Sigma Chemicals Co, St. Louis, MO, USA). It was dissolved in cold $0.01 \mathrm{M}$ citrate buffer, $\mathrm{pH} 4.5$ and always freshly prepared for immediate use within $5 \mathrm{~min}$. STZ injections were given intraperitoneally and the doses were determined according to the body weight of animals (Hamilton et al., 1998). Zoledronic acid was purchased it from Global Napi pharmaceuticals Co. (Metadronic vial) and injected by $0.15 \mathrm{mg} / \mathrm{kg}$ BW through the tail vein.

\section{Sampling:}

At 14 and 28 day after treatment start, blood samples were collected in centrifugation tubes from four rats per each treatment without anticoagulant and kept at room temperature for one hour to clot. The samples were centrifuged at $3500 \mathrm{rpm}$ for 15 minutes to separate clear serum. After that, serum glucose (Trinder, 1969), insulin (Flier et al., 1979), calcium (Farell, 1984a), phosphorus (Farell, 1984b) and vitamin D (Clemens, 1986) were determined using available commercial Kits.

\section{Statistical analysis:}

Data obtained were statistically analyzed using the general linear model of SAS (2004), as follows: $\mathrm{Yik}=\mu+\mathrm{Ti}++$ eik where : Yik $=$ an observation; $\mu=$ Overall mean; $\mathrm{T}=$ Effect of treatment; $i=(1,2, .$. and 5$)$; and eik $=$ Random error. Significant differences among treatments means were tested by Duncan's multiple range test (Duncan, 1955).

\section{RESULTS}

A significant differences $(\mathrm{P} \leq 0.01)$ were observed in serum glucose at 14 and 28 day after treatment among different experimental groups (Table 1). Rats injected with STZ with or without ZOL had significantly $(\mathrm{P} \leq 0.01)$ higher serum glucose value than the control group (non -treated) at 14 and 28 day after injection. However, serum glucose level was significantly elevated in rats injected by 60 mg STZ/ kg as compared with other treated groups. Serum glucose level was insignificantly decreased by $26.13 \%$ of the group injected with ZOL plus $30 \mathrm{mg} \mathrm{STZ/} \mathrm{kg}$ as compared with those injected with $30 \mathrm{mg}$ 
STZ only, while it was significantly decreased by $47.47 \%$ by treatment with ZOL plus $60 \mathrm{mg}$ STZ/ kg as compared with those treated with $60 \mathrm{mg}$ STZ only. On the other hand, serum glucose level was elevated at 28 day after injection for groups injected with both 30 or $60 \mathrm{mg} \mathrm{STZ} / \mathrm{kg}$ as compared with the same groups at 14 day after injection, however the groups treated with ZOL plus 30 or $60 \mathrm{mg}$ STZ/kg had lower values of serum glucose at 28 day after the injection as compared with the same groups at 14 day after treatment.

All injected groups by STZ with or without ZOL had significantly $(\mathrm{P} \leq 0.01)$ lower serum insulin value than the control group at 14 and 28 day after the injection (Table 1). Rats injected with $60 \mathrm{mg} \mathrm{STZ/kg} \mathrm{had} \mathrm{lower} \mathrm{serum}$ insulin than all experimental groups, however serum insulin value was significantly elevated of rats treated with ZOL plus 30 or $60 \mathrm{mg}$ STZ/ kg at the same time as compared with rats injected by the same STZ doses only. Serum insulin level was significantly elevated by $23.70 \%$ for rats injected with $30 \mathrm{mg} \mathrm{STZ}$ plus ZOL, as compared with those injected with $30 \mathrm{mg}$ STZ only, while it was significantly higher by $89.66 \%$ for the group treated with ZOL plus $60 \mathrm{mg} \mathrm{STZ}$ than those injected with $60 \mathrm{mg} \mathrm{STZ}$ only at 14 day after treatment. Serum insulin recorded the high level for rats injected by ZOL plus STZ doses at 28 day after treatment than the same groups at 14 day.

Results of Table 1 showed a significant differences $(\mathrm{P} \leq 0.01)$ in serum level among experimental groups at 14 and 28 day after treatment. Serum calcium level was significantly lower for rats injected by 30 or $60 \mathrm{mg} \mathrm{STZ} \mathrm{/} \mathrm{kg} \mathrm{BW} \mathrm{with} \mathrm{or} \mathrm{without} \mathrm{ZOL}$ than the control group. However, it was elevated as a result of ZOL injection plus STZ as compared with those reated with STZ only at 14 and 28 day after treatment. Moreover, the injection with ZOL plus different STZ doses resulted in approximately similar values of serum calcium at 14 and 28 day after treatment.

A significant differences were recorded $(\mathrm{P} \leq 0.01)$ in serum phosphorus level among experimental groups at 14 day after treatment only (Table 1). Serum phosphorus was elevated for all treated groups except of the group injected with $60 \mathrm{mg} \mathrm{STZ/} \mathrm{kg}$ at 14 day after treatment. However, serum phosphorus level was significantly elevated as a result of the injection with ZOL plus different STZ doses at 14 day after treatment. Serum phosphorus content was approximately similar for all treated group as compared to the control at 28 day.

Moreover, a significant differences $(\mathrm{P} \leq 0.01)$ was recorded in serum vitamin $\mathrm{D}$ among experimental groups at 14 and 28 day after treatment (Table1). Serum vitamin D was significantly lowered for all rats injected by 30 or $60 \mathrm{mg} \mathrm{STZ} \mathrm{/} \mathrm{kg}$ with or without ZOL treatment than the control group except of those treated with ZOL plus $60 \mathrm{mg} \mathrm{STZ}$ at 14 day after treatment. Moreover, injection 60 $\mathrm{mg}$ STZ resulted in a significant decrease in serum vitamin $D$ level than other treated and the control groups at 14 day after treatment. The injection with ZOL plus STZ at the same time resulted in elevation of vitamin $\mathrm{D}$ level showed significant effect as compared with those treated with STZ only at 14 or 28 day after treatment. 
Table 1: Effect of zoledronic acid on some serum biochemical parameters on STZ induced pancreatic damage at 14 and 28 day of treatment.

\begin{tabular}{|c|c|c|c|c|c|c|}
\hline \multirow[t]{2}{*}{ Parameters } & \multirow{2}{*}{$\begin{array}{l}\text { Control (- } \\
\text { ve) }\end{array}$} & \multicolumn{2}{|c|}{$\mathrm{STZ}, \mathrm{mg} / \mathrm{kg}$} & \multicolumn{2}{|c|}{$\begin{array}{l}\text { STZ }(\mathrm{mg}) \mathrm{kg})+\mathrm{ZOL} \\
(0.15 \mathrm{mg} / \mathrm{kg})\end{array}$} & \multirow[t]{2}{*}{ Sig. } \\
\hline & & 30 & 60 & 30 & 60 & \\
\hline \multicolumn{7}{|c|}{ Serum constituents at 14 day after treatment } \\
\hline Glucose , mg/dl & $\begin{array}{l}87.64 \pm \\
2.86^{\mathrm{c}}\end{array}$ & $\begin{array}{l}184.12 \pm \\
20.43^{b}\end{array}$ & $\begin{array}{l}287.00 \pm \\
20.30^{\mathrm{a}}\end{array}$ & $\begin{array}{l}136.00 \pm \\
10.51^{\mathbf{b c}}\end{array}$ & $\begin{array}{l}150.75 \pm \\
25.10^{\mathbf{b}}\end{array}$ & ** \\
\hline Insulin, $\mu \mathrm{U} / \mathrm{L}$ & $\begin{array}{l}17.66 \pm \\
0.32^{\mathrm{a}}\end{array}$ & $8.10 \pm 0.59^{c}$ & $5.90 \pm 0.69^{d}$ & $10.02 \pm 0.35^{\mathbf{b}}$ & $11.19 \pm 0.05^{b}$ & $* *$ \\
\hline Calcium, mg/dl & $\begin{array}{l}9.19 \pm \\
0.12^{\mathrm{a}}\end{array}$ & $7.80 \pm 0.17^{\mathbf{b}}$ & $7.15 \pm 0.07^{\mathrm{c}}$ & $8.05 \pm 0.20^{b}$ & $7.95 \pm 0.22^{b}$ & $* *$ \\
\hline $\begin{array}{l}\text { Phosphorus, } \\
\mathrm{mg} / \mathrm{dl}\end{array}$ & $\begin{array}{l}4.97 \pm \\
0.36^{\mathbf{b}}\end{array}$ & $5.45 \pm 0.16^{\mathbf{a b}}$ & $4.79 \pm 0.22^{\mathbf{b}}$ & $5.93 \pm 0.14^{\mathrm{a}}$ & $6.13 \pm 0.17^{\mathrm{a}}$ & $* *$ \\
\hline Vit. D , pg/ml & $\begin{array}{l}36.52 \pm \\
2.79^{\mathrm{a}}\end{array}$ & $28.05 \pm 1.78^{\mathbf{b}}$ & $21.41 \pm 1.33^{\mathrm{c}}$ & $29.03 \pm 2.38^{\mathbf{b}}$ & $30.78 \pm 0.91^{\mathbf{a b}}$ & $* *$ \\
\hline \multicolumn{7}{|c|}{ Serum constituents at 28 day after treatment } \\
\hline Glucose , mg/dl & $\begin{array}{l}87.64 \pm \\
2.86^{\mathrm{d}}\end{array}$ & ${ }_{b} 193.22 \pm 19.43$ & $321.25 \pm 2.10$ & $107.64 \pm 5.09$ & $120.50 \pm 5.39^{\mathrm{c}}$ & $* *$ \\
\hline Insulin, $\mu \mathrm{U} / \mathrm{L}$ & $\begin{array}{l}17.66 \pm \\
0.32^{\mathrm{a}}\end{array}$ & $9.96 \pm 0.22^{d}$ & $8.06 \pm 0.23^{d}$ & $11.71 \pm 0.54^{\mathrm{c}}$ & $13.04 \pm 0.13^{\mathbf{b}}$ & $* *$ \\
\hline Calcium, mg/dl & $\begin{array}{l}9.19 \pm \\
0.12^{\mathrm{a}}\end{array}$ & $7.45 \pm 0.09^{\mathrm{c}}$ & $7.00 \pm 0.06^{\mathbf{d}}$ & $8.09 \pm 0.06^{\mathbf{b}}$ & $7.24 \pm 0.13^{\mathrm{cd}}$ & $* *$ \\
\hline $\begin{array}{l}\text { Phosphorus, } \\
\mathrm{mg} / \mathrm{dl}\end{array}$ & $4.97 \pm 0.36$ & $4.75 \pm 0.22$ & $4.58 \pm 0.23$ & $4.77 \pm 0.22$ & $5.16 \pm 0.10$ & NS \\
\hline Vit. D, pg/ml & $\begin{array}{l}36.52 \pm \\
2.79^{\mathrm{a}}\end{array}$ & $27.91 \pm 3.36^{\mathbf{b}}$ & $26.03 \pm 1.74^{\mathrm{b}}$ & $29.29 \pm 1.89^{a b}$ & $30.64 \pm 3.63^{\mathrm{ab}}$ & $* *$ \\
\hline
\end{tabular}

a,b,c... d :means in the same row within each item bearing different superscripts are significantly different $(\mathrm{P} \leq 0.05), * *=$ significant at $\mathrm{P} \leq 0.01 ; \mathrm{NS}=$ non-significant

treatment at once caused a significant decrease in the elevation of serum glucose

\section{DISCUSSION}

During the first two or four weeks after STZ injection, glycemia rose in all treated rat groups with 30 or $60 \mathrm{mg} \mathrm{STZ} / \mathrm{kg} \mathrm{BW}$, suggesting similar acute STZ toxic effects on the endocrine pancreas. These results may be due to pancreatic $\beta$-cells were degenerated or necrosis by STZ injection, leading a decrease in insulin secretion and an increase in blood glucose concentration. These results were in agreement with those obtained by Sireesha and Ragunandan (2017) who reported that blood insulin was decreased while blood glucose levels were elevated above $250 \mathrm{mg} / \mathrm{dl}$ of rats indicated- diabetic by using STZ at a dose of $30-50 \mathrm{mg} / \mathrm{kg}$. But after zolderonic acid than non-treated group at 14 and 28 day after treatment. The decrease in serum glucose by ZOL treatment plus STZ at once may be due to zoledronic acid has a direct effect on the primary tumor and plays a major role as antitumor activity (Tassone et al., 2003 ; Marten et al., 2007). Also, ZOL injection at the initial treatment of pancreatic degeneration by STZ may resulted in a delay of induce pancreatic carcinoma. Also, decrease serum glucose as a result of ZOL injection with STZ at once, may be due to ZOL acid resulted in a decrease of STZ capacity to induce pancreatic tumor for $\beta$-cells because ZOL by inhibit a key enzyme, farnesyl diphosphonate (FPP) 
synthase, in the biosynthetic mevalonate pathway (Zekri et al., 2014)

A significant decrease in serum calcium content at 14 and 28 day after STZ injection, while it was insignificantly elevated by ZOL treatment with both STZ doses at once. The elevation of serum calcium as a results of injection ZOL plus both STZ doses may be due to bisphosphonates that may have antitumor effect as well as it effective in preventing/delaying skeletal-related events in patients with bone metastases and potentially preserving functional in dependence and quality of life (Zekria et al., 2014). This effect is mediated by the inhibitory effect of nitrogen-containing bisphosphonates which prevent tumour cell invasion that intrinsically linked to localized cell surface proteolytic activity driven by matrix metalloproteinases (MMPs), which facilitates cell detachment from matrix proteins, thereby promoting cell migration (Clezardin et al., 2003). However, serum phosphorus was elevated as a result of STZ treatment plus ZOL at 14 day after treatment which may be due to a paradoxical metabolic imbalance in phosphate $(\mathrm{P})$, which occurs at the early onset of diabetes and may lead to a reduction of high energy phosphates and tissue hypoxia. These changes take place in the cells and tissues in which the entry of glucose is not controlled by insulin and particularly in poorly regulated diabetes patients in whom long- term vascular complications are more likely to occur (Ditzel and Lervang, 2009). Also, it may due to a disturbance in phosphate handling, which occurs in the kidney tubules, where the excessive sodium-dependent glucose entry in diabetics depolarizes the electrochemical sodium gradient and consequently impairs $\mathrm{P}$ reabsorption. Similar changes may occur in other cells and tissues in which glucose entry is not controlled by insulin and particularly in poorly-regulated diabetic patients in whom long-term vascular complications are more likely (Ditzel and Lervang, 2010). Moreover, the diminution in urinary phosphorus loss may have been due to diminished glycosuria but equally could have been influenced by a direct action of insulin on the renal tubule or suppression of glucagon and parathyroid hormone secretion. Under such conditions reduced urinary $\mathrm{P}$ may have been sufficient to cause a rise in serum $\mathrm{P}$ despite the known effects of insulin on the cellular influx of $\mathrm{P}$ (Raskin and Pak, 1981). These results are in agreement with those obtained by Kebler et al., 1985 who reported that phosphate depletion is common in diabetic ketoacidosis. Initially intracellular phosphate moves to extracellular compartment due to acidosis, dehydration (Raul et al. (2015) who found that phosphate excretion is increased in diabetics, especially those with uncontrolled one.

In current results, the decrease of viamin $\mathrm{D}$ as a result of pancreatic degeneration by STZ treatment in the same line with $\mathrm{Wu}$ et al. (2015) who reported that serum 25(OH) D level was significantly decreased for diabetic rats than those un-diabetic, this may be due to DM may reduce bone mineral content and negatively interfere with the process of implant fixation. Injection of ZOL plus STZ at once resulted in elevating serum vitamin D than those treated with STZ only. These results may be due to Zoledronic acid is a potent and innovative third generation nitrogen-containing biphosphonate that is administered intravenously with rapid absorption and concentration in the maxillary and mandibular structure. Or it may act directly or indirectly on osteoblasts and osteoclasts resulting in decreased bone turnover, and exert inhibitory effects on inflammatory mediators affecting the healing process of bone lesions (Wayama et al., 2015). 


\section{Conclusion}

Based on the present data, treatment by zoledronic acid $(0.15 \mathrm{mg} / \mathrm{kg})$ combined with STZ (30 or $60 \mathrm{mg} / \mathrm{kg}$ ) might be attributed to an inhibition of invasion and proliferation of cancer cells of pancreatic. So, the therapy with zoledronic may show a great promise for the treatment of pancreatic degeneration at the further, and well needed a lot of further studies to examine the clinical efficacy of this drug regimen are warranted

\section{REFERENCES}

Clemens, T.E., 1986. Vitamin D: Recent advances in basic research and clinical assay methodology. J Clin Immunoass, 9(4):183

Clezardin, P.; Fournier P.; Boissier S. and Peyruchaud O., 2003. In vitro and in vivo antitumor effects of bisphosphonates. Curr Med Chem., 10(2):173-80 .

Ditzel, J. and Lervang H.H., 2010. Disturbance of inorganic phosphate metabolism in diabetes mellitus: its impact on the development of diabetic late complications. Diabetes Rev., 6(5):323-333.

Ditzel, J. and Lervang H. H., 2009. Disturbance of inorganic phosphate metabolism in diabetes mellitus: temporary therapeutic intervention trials. Diabetes Metab. Syndr. Obes., 2:173-177.

Drake, M.T.; Clarke B.L. and Khosla S., 2008. Bisphosphonates: mechanism of action and role in clinical practice. Mmechanism of action and role in clinical practice. Mayo Clinic Proc., 83:1032-1045
Farell, E. C., 1984 a. Clin Chem. The C.V. Mosby Co. St Louis. Toronto. Princeton, 1051-1255 and 418.

Farrell, E. C., 1984b. Clin Chem. The C.V. Mosby Co. St Louis. Toronto. Princeton, 1072-1074 and 1418

Flier, J. S.; Kahn C. R. and Roth J., 1979. Receptors, antireceptor antibodies and mechanisms of insulin resistance. $\mathrm{N}$. Engl. J. Med., 300: 413-418.

Hamilton, K.; Eaton E.J.; Garland H.O. and Old S., 1998. Effects of experimental diabetes mellitus on Gentamicininduced acute renal functional changes in the anesthetized rats.Clinical experimental Pharmacology and Physiology, 25: 231-235.

Kebler, R.; McDonald F.D. and Cadnapaphornchai P., 1985. Dynamic changes in serum phosphorus levels in diabetic ketoacidosis. Am J Med., 79(5):571-576

Lenzen, S., 2008. The mechanisms of alloxan- and streptozotocininduced diabetes. Diabetologia 51:216-226

Marten, A.; Lilienfeld-Toal M.; Buchler M.W. and Schmidt J., 2007. Zoledronic acid has direct antiproliferative and antimetastatic effect on pancreatic carcinoma cells and acts as an antigen for delta2 gamma/delta $\mathrm{T}$ cells. J Immunother. 30(4):370-377

Németh, B.C.; Várkonyi T.; Somogyvári F.; Lengyel C.; Fehértemplomi K.; Nyiraty S.; Kempler P. and Mándi Y., 2014. Relevance of defensins (HNP1-3) and defensin $\beta-1$ in diabetes. World Journal of Gastroenterology [Accepted for publication] IF: 2.547

Raskin, P. and Pak C.Y., 1981. The effect of 
chronic insulin therapy on phosphate

metabolism in diabetes mellitus.

Diabetologia. 21(1):50-53

Sirmahan, C.; Firat S. and Cengizhan K., 2012. Bisphosphonates and Bone, Orthopedic Surgery, Dr Zaid AlAubaidi (Ed.)

Tassone, P.; Tagliaferri P.; Viscomi C.; Palmieri C.; Caraglia M.; D’Alessandro A.; Galea E.; Goel A.; Abbruzzese A.; Boland C.R. and Venuta S., 2003. Zoledronic acid induces antiproliferative and apoptotic effects in human pancreatic cancer cells in vitro. $\mathrm{Br} \mathrm{J}$. Cancer, 88(12):1971-1978

Tassone, P.; ForcinitiS.; Galea E.; Morrone G.; Turco M. C.; Martinelli V.; Tagliaferri P. and Venuta S., 2000. "Growth inhibition and synergistic induction of apoptosis by zoledronate and dexamethasone in human myeloma cell lines," Leukemia, Vol. 14, No. 5, pp. 841-844.

Trinder, P., 1696. Ann Clin Biochem, 6: 2433.

Wayama, M.T.; Yoshimura H.; Ohba S.; Yoshida H.; Matsuda S. and Kobayashi J., 2015. Diminished progression of periapical lesions with zoledronic acid in ovariectomized rats. J. Endod ., 41:2002-2007.

Wu, D.; Ma J.; Bao S. and Guan H., 2015. Continuous effect with long-term safety in zoledronic acid therapy for polyostotic fibrous dysplasia with severe bone destruction. Rheumatology International, 35(4), 767-772.

Zekria J.; Maged M. and Syed M.K., 2014. The anti-tumour effects of zoledronic acid. Journal of Bone Oncology, 3: 